\title{
Regrowth and production of herbaceous riparian vegetation following defoliation
}

\author{
CHAD S. BOYD AND TONY J. SVEJCAR
}

Authors are Rangeland Scientists, USDA-Agricultural Research Service, Eastern Oregon Agricultural Research Center, 67826-A, Hwy 205, Burns, Ore. 97720. The Eastern Oregon Agricultural Research Center is jointly operated by the USDA-ARS and the Oregon State University Agricultural Experiment Station.

Abstract

Stubble height regulations are frequently used to manage livestock grazing of herbaceous riparian vegetation. The objective of this study was to determine the impact of stubble height, time of clipping and soil water status on production and regrowth of herbaceous riparian vegetation. We used a randomized block design with 4 study sites on each of 3 small ( $<2 \mathrm{~m}$ width) streams in northern Harney County, Ore. In June and July of 2000-2003, $40 \times 50 \mathrm{~cm}$ experimental plots were clipped to stubble heights of 5.1 ( 2 inch), 10.2 (4 inch), or $15.2 \mathrm{~cm}$ (6 inch), and paired control plots were left unclipped. Complete treatment sets were located adjacent to the stream and $4 \mathrm{~m}$ from the stream at each site. All plots were clipped to $1 \mathrm{~cm}$ in October and regrowth was calculated by comparing clipped and control plots. Water table depth was measured weekly using PVC wells. Results indicate that height regrowth was associated positively with stubble height (P $<0.01)$ and was less with July compared to June clipping ( $P=$ 0.02 ). Weight regrowth was also positively related to stubble height $(P<0.01)$ and decreased with July compared to June clipping $(P=0.04)$ whereas annual aboveground production increased with July clipping $(P=0.02)$. Annual production values for clipped plots were higher than for unclipped plots, indicating compensatory production in response to defoliation. Plots distant from the stream had less water availability, but regrowth and production were not strongly influenced by distance from active stream channel. Timing and intensity of defoliation were reliable predictors of regrowth and production performance. Most clipping height $x$ time combinations produced end of season heights sufficient to meet current federal stubble height requirements (i.e., $10-15 \mathrm{~cm}$ ). Our results provide insight on the timing and intensity of defoliation that will allow for adequate regrowth to meet different management objectives. However, other factors such as stream channel morphology, animal selectivity, and annual weather variation will need to be considered.

Key Words: grazing, clipping, stubble height, compensatory growth

\footnotetext{
The authors wish to thank Jose' Zamora and numerous summer employees for assistance in field data collection for this research project. We also thank our cooperators Mark and Susan Doverspike, Don and Cathy Dryer, and the Burns District of the Bureau of Land Management.

Manuscript accepted 6 Mar. 2004.
}

Las reglas de altura del rastrojo son frecuentemente usadas para manejar el apacentamiento del ganado de la vegetación herbácea ribereña. El objetivo de este estudio fue determinar el impacto de la altura del rastrojo, la época de corte y el estado del agua del suelo en la producción y rebrote de la vegetación herbácea ribereña. Usamos un diseño de bloques al azar con 4 sitios de estudio en cada uno de 3 arroyos pequeños $(<2 \mathrm{~m})$ situados al norte de Oregon en el condado Harney. En Junio y Julio del 2000-2003, se cortaron parcelas experimentales de 40 x 50 m a diferentes alturas del rastrojo: 5.1 ( 2 pulgadas), 10.2 (4 pulgadas), or $15.2 \mathrm{~cm}$ (6 pulgadas) las cuales estuvieron apareadas a parcelas control que se dejaron sin cortar. En cada sitio grupos completos de los tratamientos se localizaron junto a la corriente y a $4 \mathrm{~m}$ alejados de ella. En Octubre todas las parcelas se cortaron a una altura del rastrojo de $1 \mathrm{~cm}$ y el rebrote se calculó comparando las parcelas cortadas y sin cortar. La profundidad del manto freático se midió semanalmente usando pozos de PVC. Los resultados indican que la altura del rebrote estuvo asociada positivamente con la altura del rastrojo $(P<0.01)$ y fue menor con el corte de Julio en comparación con el de Junio $(P=\mathbf{0 . 0 2})$. El peso del rebrote también estuvo positivamente relacionado con la altura del rastrojo $(P<0.01)$ y disminuyo en el corte de Julio comparado con el de Junio $(P=0.04)$, mientras que la producción anual de biomasa aérea se incrementó con el corte de Julio $(P=\mathbf{0 . 0 2})$. Los valores de producción anual para las parelas cortadas fueron mayores que los de las parcelas sin corte, indicando una producción compensatoria en respuesta a la defoliación. Las parcelas distantes de la corriente tuvieron menos disponibilidad de agua, pero el rebrote y la producción no fueron fuertemente influenciados por la distancia del canal activo. La época e intensidad de defoliación fueron variables confiables para predecir el comportamiento del rebrote y la producción. La mayoría de las combinaciones altura $\mathrm{x}$ época produjeron al final de la estación alturas del rastrojo adecuadas para cumplir con los requerimientos federales de altura al respecto, esto es, 10 - 15 $\mathrm{cm}$. Nuestros resultados aumentan el conocimiento sobre la época e intensidad de defoliación que permitirá un rebrote adecuado para satisfacer diferente objetivos de manejo. Sin embargo, otros factores tales como la morfología del canal de la corriente, la selectividad animal y las variaciones climáticas anuales necesitaran ser consideradas.

End-of-growing season herbaceous stubble height is an important consideration for managers of riparian areas grazed by livestock. Residual vegetation can influence riparian ecosystem structure and function by filtering (Clary et al. 1996) and stabiliz- 
ing (Skinner 1998) water-born sediments, thus encouraging streambank development and improving soil water storage capacity and site conditions for riparian associated plant species (Kauffman and Krueger 1984, Clary and Webster 1990, Winward 1994, Pearce et al. 1998, Clary 1999, Clary and Leininger 2000). Development of stubble height guidelines in systems grazed by livestock is a difficult task involving knowledge of a) the relationship between stubble height and sediment deposition (Skinner 1998), b) the regrowth dynamics of riparian vegetation following grazing (i.e., can the vegetation regrow by the end of the growing season to meet desired conditions) (Clary 1995), c) the interaction of stubble height and streambank degradation (Clary and Leininger 2000), and d) special habitat considerations such as optimizing stubble height for wildlife needs (e.g. Neel 1980). Previous research indicates that both timing and intensity of defoliation can impact production and regrowth of herbaceous riparian vegetation (Pond 1961, Clary 1995, Sheeter and Svejcar 1997). However, only a limited number of studies (e.g., Clary 1995) have addressed the simultaneous effects of timing and intensity of defoliation, or the influence of environmental factors on regrowth and production dynamics of riparian communities. Our objective was to determine the impact of timing and intensity of defoliation and site water status on regrowth and aboveground production of herbaceous riparian species.

\section{Methods}

\section{Experimental design}

Our study incorporated a randomized block design with split plots within blocks. We utilized 3 small ( $<2$ m width) C channel (Rosgen 1994) streams in Harney County, Ore. (4331'15", $\left.119^{\circ} 01^{\prime} 15^{\prime \prime} \mathrm{W}\right)$. On each creek we selected 4, 5 × 10 m research sites (blocks, Fig. 1). Sites ranged in elevation from 1200 to $1400 \mathrm{~m}$. We did not collect meteorological data at research sites, however, long term (30 year) data for local weather stations within this elevational band suggests 25 to $33 \mathrm{~cm}$ of annual precipitation (mainly from snowfall) and $<160$ freeze-free days (NOAA data 2003). All sites had a history of moderate $(40-60 \%$ of current years growth) growing season use by cattle. Electric fencing was established around each block in April of 2000 and data were collected during 2000-2003. Plant community types varied across and within streams and included sedge, rush, and grass dominated stands. Predominate sedges included Nebraska sedge (Carex nebraskensis Dewey.) and wooly sedge (C. lanuginosa Michx.), dominant grasses were Kentucky bluegrass (Poa pratensis L.) and redtop (Agrostis spp. L.), and baltic rush (Juncus balticus Willd.) was the most common rush. Treatments were applied within macroplots (split plots) located within $1 \mathrm{~m}$ ("close") and $4 \mathrm{~m}$ distant ("far", Fig. 1) from the edge of the stream. In all cases, the "far" plots remained within the stream's zone of hydrophytic influence. This design allowed for increased variability in soil water status within site.

We located $40 \times 50 \mathrm{~cm}$ paired treated (clipped) and control (unclipped) plots in each macroplot (Fig. 1). Each plot pair was randomly assigned to a clipping date and stubble height combination (Fig. 1). We chose to pair control and treated plots because of within site variability in standing crop. Plots were raked in May of each year to remove dead plant material and debris from high flow. Following the initial data collection season we mowed all sites to $2.5 \mathrm{~cm}$ in October of each year to minimize over-winter damage from small mammals. Water table depth to $50 \mathrm{~cm}$ was measured weekly in perforated PVC wells (Law et al. 2000, Fig. 1). We chose this depth because the vast majority of fine roots of riparian graminoids are located within $50 \mathrm{~cm}$ of the soil surface, with most occurring in the first $20 \mathrm{~cm}$ (Manning et al. 1989, Svejcar and Trent 1995). Two wells were present in each macroplot and values were averaged within macroplot to obtain weekly readings. We expressed water table depth for each macroplot in 10 $\mathrm{cm}$ categories based on the percent of the growing season (number of days) depth was within each category. Graminoid species composition was determined in 2003 based on frequency of occurrence in 12 , equally spaced $10 \mathrm{~cm}$ quadrats in each macroplot.

\section{Clipping treatments}

Plots were clipped to 5.1 ( 2 inch), 10.2 (4 inch), or $15.3 \mathrm{~cm}$ (6 inch), in either late June or July. Most herbaceous species were in early flower at the time of the June clipping and seeds were nearing maturity by the July clipping. All plots, including the controls, were clipped to $1 \mathrm{~cm}$ at the end of each growing season (October), and regrowth and annual (season long) aboveground production were determined. Regrowth was calculated by dividing the end-of-growing season (October) weight or average height of the treated plots by that of their paired control plot. Thus, our use of the term "regrowth" includes the growth increment following defoliation plus remaining stubble at the time of defoliation. We did not measure residue biomass remaining after clipping treatments were imposed, and thus did not calculate a
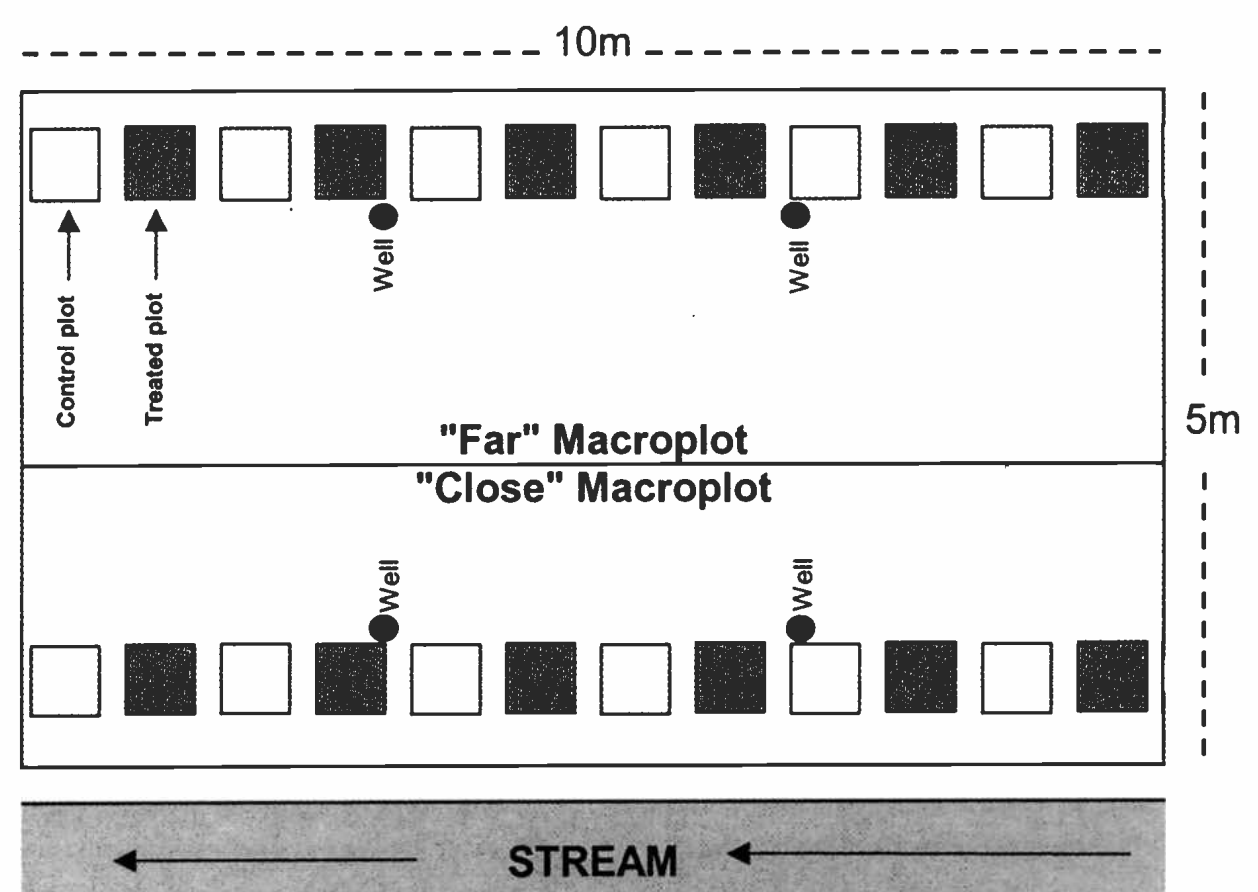

Fig. 1. The basic block design used along streams in Harney County, Ore. There were 4 such sites used along each of $3, \mathrm{C}$ channel streams. 
percent weight regrowth based on total standing crop at the time of clipping. We calculated annual production of treated plots by summing the weight of clipped vegetation across the growing season. Annual production in treated plots was also calculated as a percentage of paired control plots.

\section{Statistical analysis}

Data for annual production, annual production as a percent of control plots, and percent weight and height regrowth were transformed to meet normality assumptions prior to analysis. To test for normality, we regressed the log of site means against the log of the standard deviation, and when significant slopes were detected $(P<0.10)$, the slope value was used as an exponent in a power transformation (Montgomery 1991). For purposes of clarity, untransformed data were used in results and discussion, and transformed values were used in statistical models. Data were statistically analyzed for clipping height, time, and distance from stream channel effects on annual production and percent regrowth by weight and height using mixed model analysis of variance (PROC MIXED, SAS 1999). Clipping height, time, and distance from stream were designated as fixed effects. Main effects and interactions were considered significant at $\alpha=0.10$. When significant main or interactive effects were found we assessed differences in treatment means using the LS MEANS (SAS 1999) procedure at $\alpha=0.10$.

\section{Results}

Height regrowth was influenced by the interactive affects of clipping height $x$ clipping time, and clipping height $\mathrm{x}$ distance from active stream channel (Table 1). Values for height regrowth were generally less than $50 \%$ (of control plots) and increased with increasing clipping height
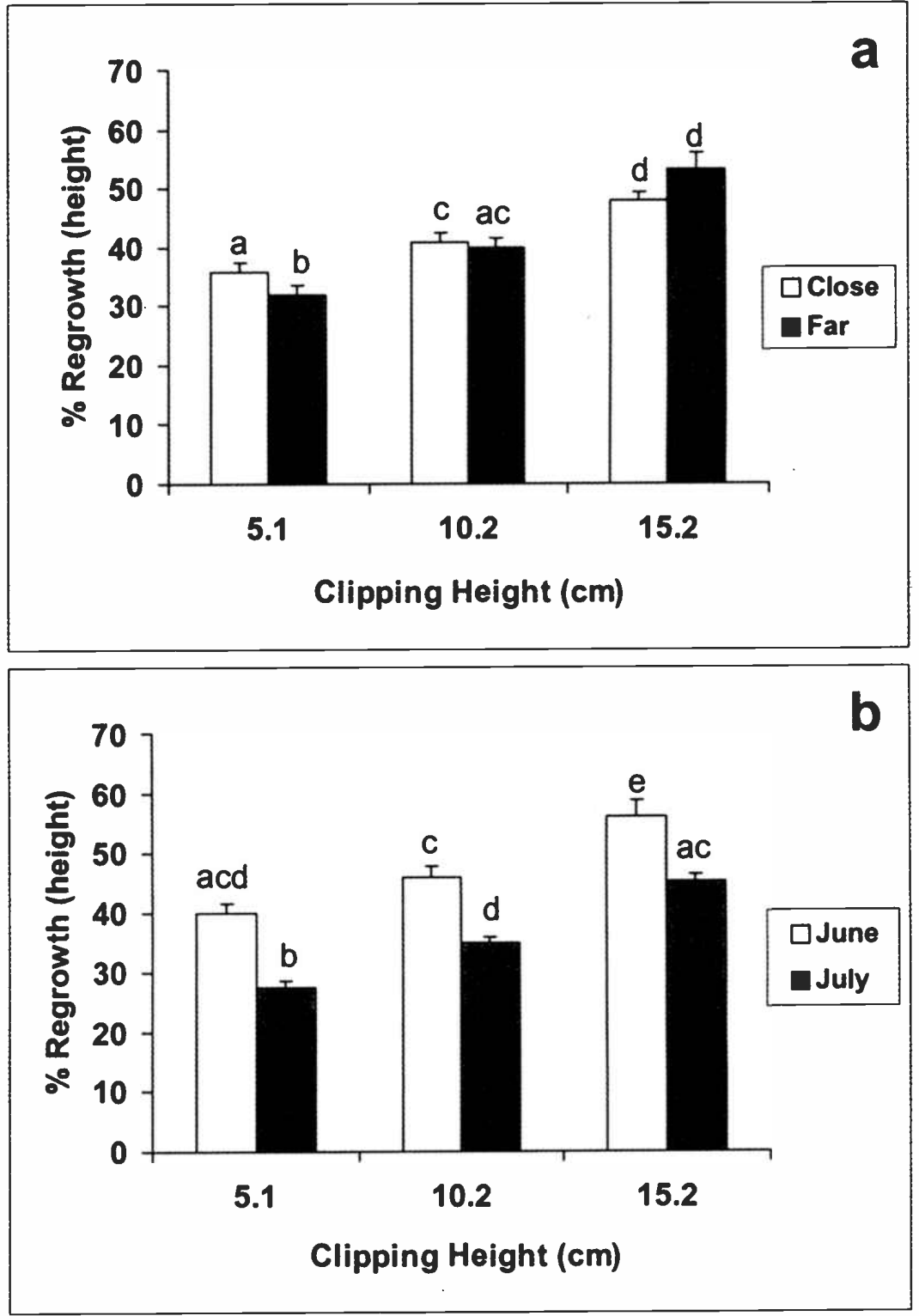

Fig. 2. The influence of clipping height and a) distance from active stream channel and b) clipping time, on percent height regrowth for herbaceous riparian plants in plots located along streams in Harney County, Ore. Regrowth was calculated by dividing end of growing season (October) height of experimental plots by that of paired control plots. Bars without a common letter are different at $\alpha=0.10$.

(Fig. 2). Distance from stream had little impact on height regrowth with the excep- tion of the $5.1 \mathrm{~cm}$ clipping height, where plots close to the stream had $13 \%$ greater

Table 1. Significant $(P<0.10)$ main effects and interactions of clipping height, clipping time, and distance from active stream channel for regrowth and production variables along small streams $(<2 \mathrm{~m}$ width) in Harney County, Ore.

\begin{tabular}{|c|c|c|c|c|c|c|}
\hline Variable & Main effects & $\overline{\mathrm{n}}$ & $\bar{P}$ & Interactions & $\bar{n}$ & $\mathrm{P}$ \\
\hline \multirow[t]{2}{*}{ Height regrowth } & Clipping height & 144 & $<0.01$ & Clipping height $\mathrm{x}$ distance & 72 & $<0.01$ \\
\hline & Clipping time & 216 & 0.02 & Clipping height $\mathrm{x}$ clipping time & 72 & $<0.01$ \\
\hline \multirow[t]{4}{*}{ Weight regrowth } & Clipping height & 144 & $<0.01$ & Clipping height $\mathrm{x}$ year & 48 & 0.04 \\
\hline & & & & Clipping height $\mathrm{x}$ distance & 72 & 0.01 \\
\hline & & & & Clipping height $\mathrm{x}$ clipping time & 72 & 0.07 \\
\hline & Clipping time & 216 & 0.04 & Clipping time $\mathrm{x}$ distance & 108 & 0.04 \\
\hline Annual production & Clipping time & 216 & 0.02 & & & \\
\hline$\%$ Annual production ${ }^{a}$ & Year & 144 & 0.04 & & & \\
\hline
\end{tabular}

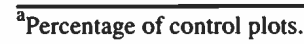


Table 2. Means and standard errors for percent composition of dominant graminoid functional groups relative to distance from active stream channel for plots located along small streams $(<2$ $\mathrm{m}$ width) in Harney County, Ore. "Close" plots are within $1 \mathrm{~m}$ of the stream edge "far" plots are $4 \mathrm{~m}$ distant.

\begin{tabular}{lccccccc}
\hline \hline & & \multicolumn{2}{c}{ Sedge } & \multicolumn{2}{c}{ Grass } & \multicolumn{2}{c}{ Rush } \\
Distance & $\mathrm{n}$ & Mean & SE & Mean & SE & Mean & SE \\
\hline \multirow{2}{*}{ Close } & 12 & $-12-0.4$ & 6.1 & 22.0 & 6.1 & 23.6 & 3.6 \\
Far & 12 & 34.3 & 6.8 & 26.5 & 3.8 & 29.7 & 5.3 \\
\hline
\end{tabular}

regrowth than far plots (Fig. 2a). Plots clipped in June had greater height regrowth at all clipping heights compared to those clipped in July, with an average increase (across clipped stubble heights) of $34 \%$ for June clipping (Fig. 2b). End of growing season height (Fig. 3) ranged from a low of $8.9 \mathrm{~cm}$ for the $5.1 \mathrm{~cm}$, far, July clipping treatment to $19 \mathrm{~cm}$ for the 15.2 $\mathrm{cm}$, far, June clipping treatment (Fig. 3).

Weight regrowth was influenced by clipping time $\mathrm{x}$ distance to active stream channel, and clipping height and its interaction with year, distance to active stream channel, and clipping time (Table 1). Values for weight regrowth ranged from approximately $45 \%$ for the $5.1 \mathrm{~cm}$ clipping to about $80 \%$ for the $15.2 \mathrm{~cm}$ clipping (Fig. 4). The influence of year on weight regrowth did not have a consistent pattern across clipping heights (Fig. 4a). Distance from stream had no effect on weight regrowth within a clipping height (Fig. 4b). Weight regrowth for the June clipping was 31,12 , and $9 \%$ greater than July clipping for the $5.1,10.2$, and $15.2 \mathrm{~cm}$ clipping heights, respectively (Fig. 4c). Values for weight regrowth in June and July did not vary by distance from stream (Fig. 4d). Annual production varied by time of clipping (Table 1) and increased from $356 \mathrm{~g} / \mathrm{m}^{2}$ for June clipping to 385 $\mathrm{g} / \mathrm{m}^{2}$ for July clipping (Fig. 5a). Weight of vegetation harvested at the time of clipping made up a greater proportion of annual production for plots clipped in July than in June (Fig. 5a). Production as a percent of control plots was influenced by year of clipping (Table 1) and ranged from $123 \%$ in 2000 to $108 \%$ for 2001 (Fig. 5b). Values for 2000 were 14 and $10 \%$ higher than 2001 and 2002, respectively (Fig. 5b).

Relative composition of dominant plant functional groups favored sedge abundance near the stream channel $(45.4 \%+/-6.1$ vs. $34.3 \%+/-6.8$ ), while grass/rush abundance tended to be higher for distant macroplots (Table 2). Depth to water table varied across year and distance from active stream channel (Table 3 ). As expected, macroplots close to the active stream channel had a greater proportion of the growing

\section{Discussion}

season with the water table within 10,20 , and $30 \mathrm{~cm}$ of the soil surface. Distant macroplots were drier with the water table within $50 \mathrm{~cm}$ of the soil surface for only $75.6 \%$ of the growing season, compared to $89.5 \%$ for close plots (across years). The water table was somewhat closer to the soil surface during 2000 as compared to 2001 and 2002.

We selected study sites to be representative of the variability of low order stream systems in southeastern Oregon. Despite the resultant variability in plant community types between and within creeks, clipped stubble height and time of clipping were strongly associated with end-of-season regrowth performance based on both height and weight. The regrowth response of plants to timing of clipping supported the hypothesis that later clipping (July) produces less regrowth than early clipping

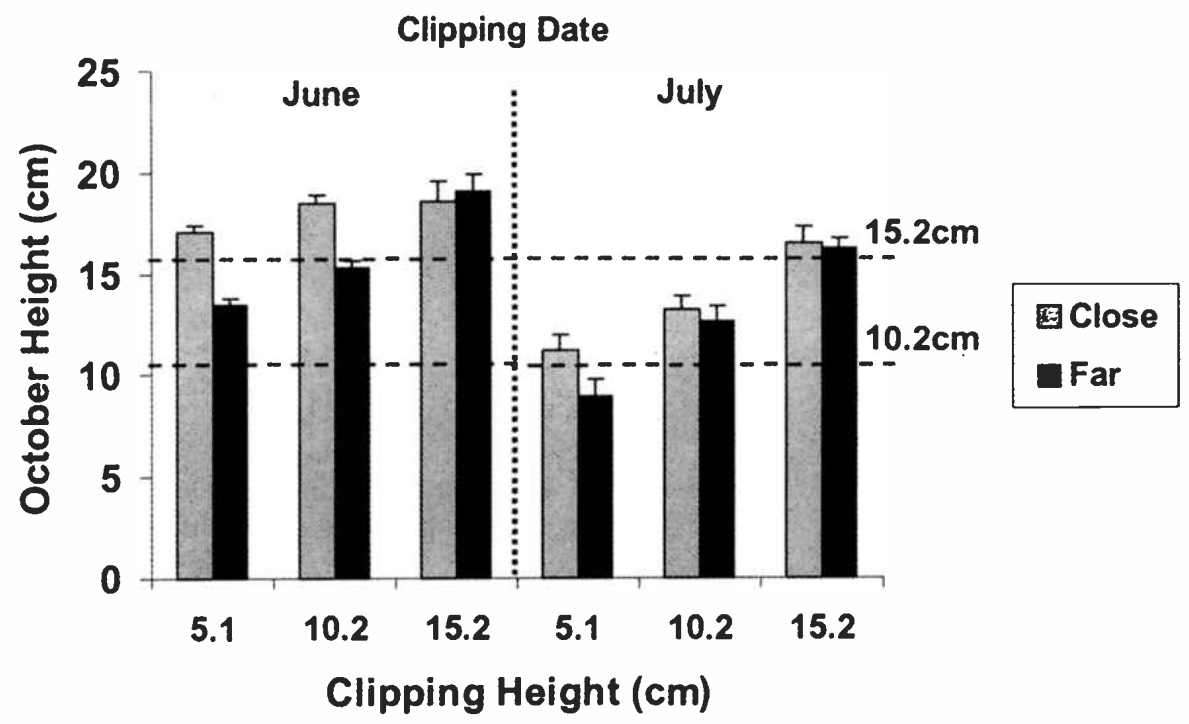

Fig. 3. The influence of clipping height, clipping time, and distance from active stream channel on end of growing season (October) height for herbaceous riparian plants in plots located along streams in Harney County, Ore. Lines have been superimposed to indicate $10.2 \mathrm{~cm}$ (4 inch) and $15.2 \mathrm{~cm}(6$ inch) stubble height requirements. 

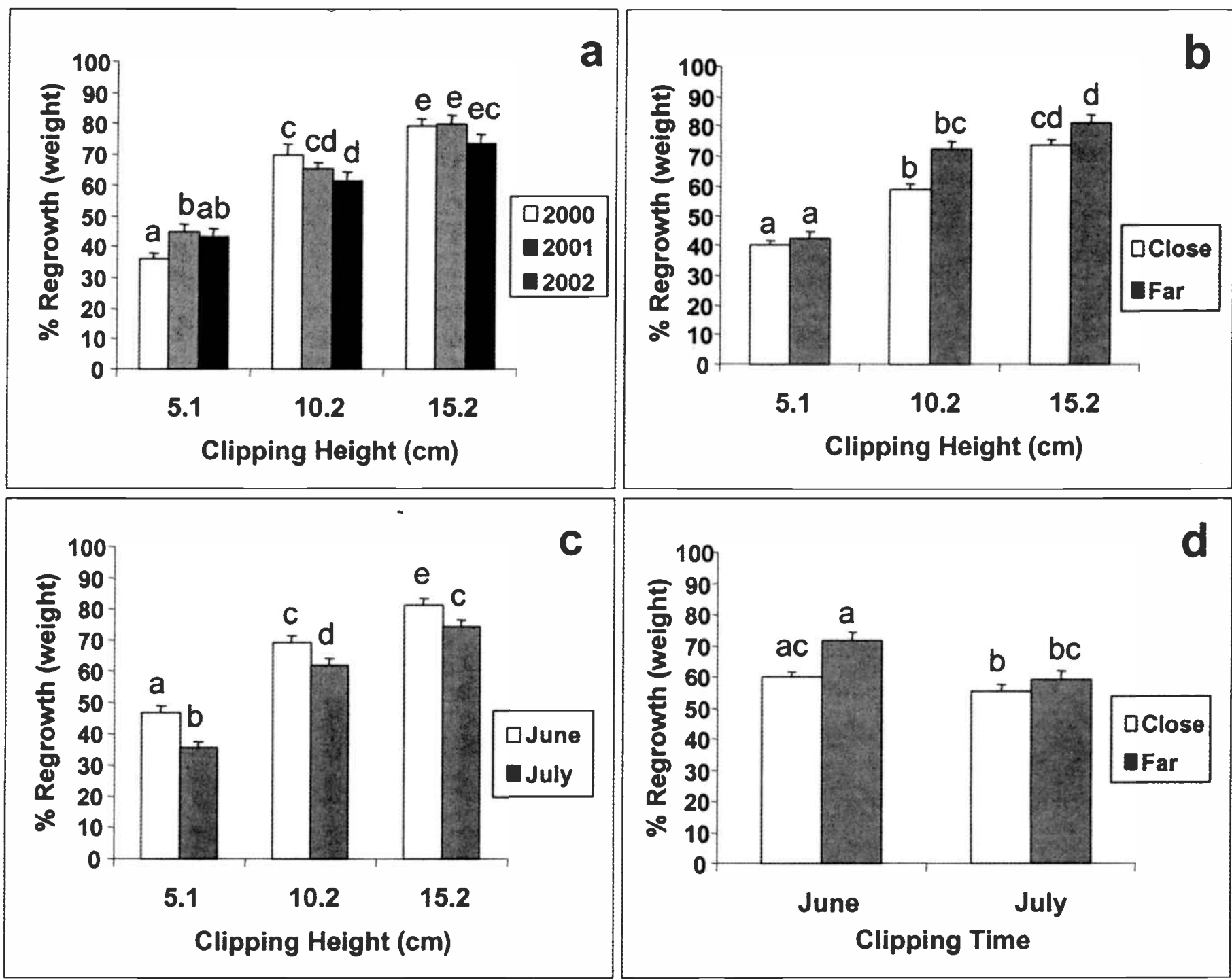

Fig 4 . The influence of a) clipping height and year, b) clipping height and distance from active stream channel, c) clipping height and clipping time, and d) clipping time and distance from active stream channel, on percent weight regrowth for herbaceous riparian plants in plots located along streams in Harney County, Ore. Regrowth was calculated by dividing end of growing season (October) weight of experimental plots by that of paired control plots. Bars without a common letter are different at $\alpha=0.10$.

may have been associated with the interactive effects of species composition and water availability. Relative composition of grasses was higher in the less mesic distant plots and sedge composition was higher in plots adjacent to the stream (more mesic, Table 2). Grasses would have tillered either from basal or below ground buds in response to defoliation which may have limited height regrowth. Limited evidence suggests that biomass production of sedges following defoliation may be less than that of grasses (Pond 1961). Additionally, Skinner (1998) noted that the vertical distribution of biomass is curvelinear for riparian grasses, and more linear for sedges. Thus, at lower stubble heights, grasses may have less of their total biomass removed than sedges.
Distant plots also had a higher abundance of rushes $(29 \%+/-1.2$ vs. $23 \%+/-0.8)$, however, the regrowth dynamics of rushes as a group has not been reported.

Table 3. Soil water table dynamics for plots located along small streams ( $<2 \mathrm{~m}$ width) in Harney County, Ore. Scores represent the percent of the growing season (mid-May through mid October) that the water table was within a specified distance of the soil surface for plots within $1 \mathrm{~m}$ of the stream edge ("close") and $4 \mathrm{~m}$ distant ("far"). Values $>50 \mathrm{~cm}$ are not reported.

\begin{tabular}{|c|c|c|c|c|c|c|}
\hline \multirow{3}{*}{$\begin{array}{l}\text { Depth to water } \\
\text { table }\end{array}$} & \multicolumn{6}{|c|}{ Year } \\
\hline & \multicolumn{2}{|c|}{2000} & \multicolumn{2}{|c|}{2001} & \multicolumn{2}{|c|}{2002} \\
\hline & Close & Far & Close & Far & Close & Far \\
\hline$(\mathrm{cm})$ & \multicolumn{6}{|c|}{ - } \\
\hline 10 & 24.4 & 9.0 & 27.7 & 4.8 & 30.8 & 4.2 \\
\hline 20 & 43.7 & 24.6 & 34.4 & 12.4 & 36.6 & 14.5 \\
\hline 30 & 65.7 & 45.0 & 55.7 & 29.9 & 57.4 & 33.9 \\
\hline 40 & 82.0 & 61.7 & 80.7 & 51.9 & 80.4 & 48.8 \\
\hline 50 & 91.4 & 76.9 & 87.7 & 79.1 & 89.3 & 70.9 \\
\hline
\end{tabular}


since clipping later in the growing season (July) resulted in greater season-long production (Fig. 5a). Absence of a year effect on annual production suggests that our clipping treatments would be sustainable over time. Production responses reported in the literature are not definitive (Pond 1961, Clary 1995, Skinner 1998). Differences in production responses between studies may be associated with species-specific responses with grassdominated communities responding more positively to defoliation than sedge communities (Pond 1961, Clary 1995). In our study, we observed a compensatory effect of clipping on annual aboveground production (i.e., annual production was higher in experimental than control plots) and the degree of compensatory production was similar across clipping treatments. Differences in compensatory production as a function of year (Fig. 5b) were related positively to soil water availability (Table 3 ), suggesting a positive association between water availability and compensatory production. Increased aboveground productivity with grazing could either take the form of increased density of shoots or accelerated growth of existing shoots (Ratliff and Westfall 1987, Allen and Marlow 1994). The mechanism for compensatory aboveground growth in our study is unclear, however, the higher absolute values for weight regrowth (as compared to height regrowth) suggest that increased shoot density was a factor. Rigorous evaluation of compensatory response of riparian graminoids to defoliation will involve examination of both below and aboveground production dynamics (Belsky 1987). Limited riparian data suggest that below ground biomass is unaffected by biweekly clipping to $2.5 \mathrm{~cm}$ stubble height over 2 years (Rumsey 1996) and for an additional two years (Gray 1998).

From a management perspective, height regrowth response at the clipping heights and times used in this study generally provided sufficient regrowth to meet end-ofgrowing season stubble height requirements on federal lands (approximately 10 to $15 \mathrm{~cm}$, or 4 to 6 inches; Clary 1995). A $5.1 \mathrm{~cm}$ (4 inch) stubble height requirement was met by all but the $5.1 \mathrm{~cm}$, far, July clipping. Conversely only about $50 \%$ of the clipping treatments (mainly those clipped in June) met a $15.2 \mathrm{~cm}$ (6 inch) requirement. Managers should consider that stubble height is only one of many tools available to gauge management impacts on resource integrity, and that our study of uniform clipping would be diffi- cult to replicate with any type of grazing except very high stocking densities. During dry years and on sites with reduced water availability (e.g. down-cut stream channels), regrowth and production values may respond less positively to defoliation at a given stubble height. Grazed stubble height may interact with season of use, with early-season grazing producing less use of riparian areas at a given stocking rate because of improved palatability of upland forages at this time (Gillen et al. 1985, Clary and Booth 1993). In a larger context, the results of the current study may apply to grazing management of meadow systems that contain riparianassociated plant species but are not directly influenced by stream hydrology. In such
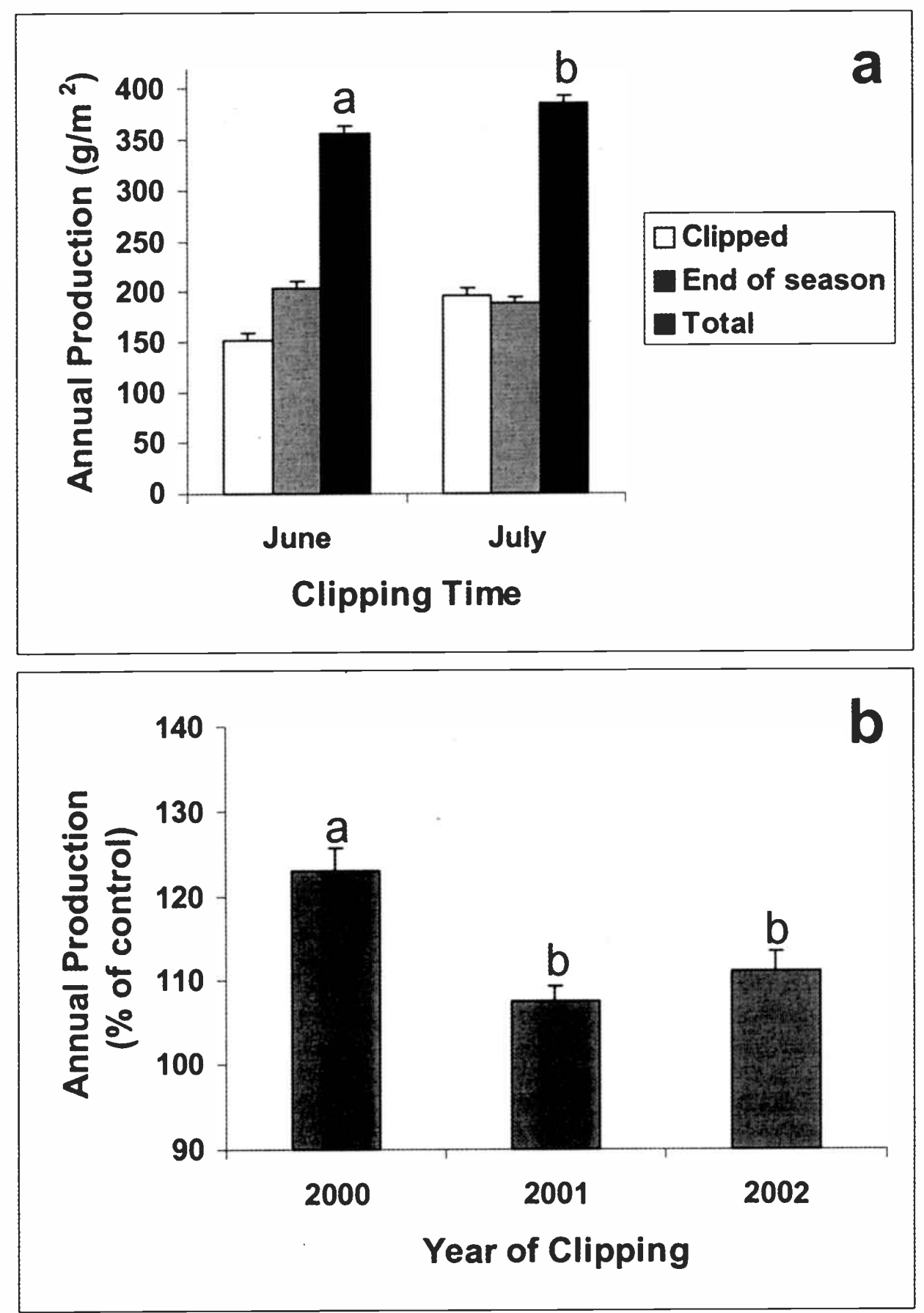

Fig. 5. The influence of a) clipping time on annual aboveground production, and b) year of clipping on annual aboveground production (expressed as a percentage of control plots), for herbaceous riparian plants in plots located along streams in Harney County, Ore. Bars without a common letter are different at $\alpha=0.10$. In figure 5a only "total" production was tested in the statistical model; "clipped" bars represent the weight of vegetation harvested at the time of clipping and "end of season" bars represent standing crop after clipping plus regrowth. 
cases, our data indicate that grazing during July can maximize annual production relative to grazing earlier in the season.

In summary, our results suggest that timing and intensity of defoliation are robust predictors of riparian graminoid regrowth and aboveground production. Most treatments imposed in the current work would produce height regrowth adequate to meet or exceed current end-ofseason stubble height regulations on federal lands. Similar production values over a 3-year time horizon suggest sustainability of the treatments used in our study. The specific regrowth and production values noted in the current work may have differed if grazing were used as opposed to clipping. First, because stocking density can influence animal selectivity which could alter regrowth response in mixed species stands, and second, because the added impact of hoof action can suppress plant growth and degrade site conditions (Clary 1995, 1999, Clary and Leininger 2000 ), however, the relative impact of mechanical vs. biotic defoliation has not been consistent (Baldwin 1990) and needs further research. We also need to improve our understanding of how various stubble heights impact below ground production dynamics, and the role of residual vegetation in influencing bank building processes and site development.

\section{Literature Cited}

Allen, D.R. and C.B. Marlow. 1994. Shoot population dynamics of beaked sedge following cattle grazing. J. Range Manage. 47:64-69.

Baldwin, I.T. 1990. Herbivory simulations in ecological research. TREE 5:91-93.
Belsky, A.J. 1987. The effects of grazing: confounding of ecosystem, community and organism scales. Amer. Mid. Nat. 129:777783.

Clary, W.P. 1995. Vegetation and soil responses to grazing simulation on riparian meadows. J. Range Manage. 48:18-25.

Clary, W.P. 1999. Stream channel and vegetation responses to late spring cattle grazing. J. Range Manage. 52:218-227.

Clary, W.P. and G.D. Booth. 1993. Early season utilization of mountain meadow riparian pastures. J. Range Manage. 46:493-497.

Clary, W.P. and W.C. Leininger. 2000. Stubble height as a tool for management of riparian areas. J. Range Manage. 53:562-573.

Clary, W.P. and B.F. Webster. 1990. Riparian grazing guidelines for the Intermountain Region. Rangelands 12:209-212.

Clary, W.P., C.I. Thornton, and S.R. Abt. 1996. Riparian stubble height and recovery of degraded streambanks. Rangelands 18:137-140.

Gillen, R.L., W.C. Kruger, and R.F. Miller. 1985. Cattle use of riparian meadows in the Blue Mountains of northeastern Oregon. J. Range Manage. 38:205-209.

Gray, C.L. 1998. The effects of three residual vegetation heights on streambank sediment deposition and vegetation production: A continuation. M.S. Thesis. Univ. Wyo., Laramie, Wyo.

Kauffman, J.B. and W.C. Krueger. 1984. Livestock impacts on riparian ecosystems and streamside management implications..A review. J. Range Manage. 37:430-438.

Law, D.J., C.B. Marlow, J.C. Mosley, S. Custer, P. Hook, and B. Leinard. 2000. Water table dynamics and soil texture of three riparian plant communities. Northwest Sci. 74:234-241.

Manning, M.E., S.R. Swanson, T. Svejcar, and J. Trent. 1989. Rooting characteristics of four intermountain meadow community types. J. Range Manage. 42:309-312.
Montgomery, D.C. 1991. Design and analysis of experiments. John Wiley and Sons, New York, N.Y.

Neel, L.A. 1980. Sage-grouse response to grazing management in Nevada. M.S. Thesis, Univ. Nev., Reno, Nev.

Pearce, R.A., G.W. Frasier, M.J. Trlica, W.C. Leininger, J.D. Stednich, and J.L. Smith. 1998. Sediment filtration in a montane riparian zone under simulated rainfall. J. Range Manage. 51:309-314.

Pond, F.W. 1961. Effect of three intensities of clipping on the density and production of meadow vegetation. J. Range Manage. 14:34-38.

Ratliff, R.D. and S.E. Westfall. 1987. Dryyear grazing and Nebraska sedge (Carex nebraskensis). Great Basin Natur. 47:422-426.

Rosgen, D.L. 1994. A classification of natural rivers. Catena 22:169-199.

Rumsey, C.J. 1996. The effect of three residual vegetation heights on streambank sediment deposition and vegetative production. M.S. Thesis. Univ. Wyo., Laramie, Wyo.

SAS Institute Inc. 1999. SAS procedures guide, release 8.0. Cary, N.C.

Sheeter, G. and T. Svejcar. 1997. Streamside vegetation regrowth after clipping. Rangelands 19:30-31.

Skinner Q.D. 1998. Stubble height and function of riparian communities, p. 29-46. In: Stubble height and utilization measurements: uses and misuses. Or. Agr. Exp. Sta. Bull. 682. Corvallis, Ore.

Svejcar, T.J. and J.D. Trent. 1995. Gas exchange and water relations of Lemmon's willow and Nebraska sedge. J. Range Manage. 48:121-125.

Winward, A.H. 1994. Management of livestock in riparian areas, p. 49-52. In: G.A. Rasmussen, and J.P. Dobrowolski (eds.) Riparian resources: a symposium on the disturbances, management, economics, and conflicts associated with riparian ecosystems. Coll. Nat. Resources, Utah. St. Univ., Logan, Ut. 